\title{
CHARACTERISTICS OF HYDROTHERMAL ALTERATION IN CIJULANG AREA, WEST JAVA, INDONESIA
}

\author{
Myo Min Tun ${ }^{* 1}$, I Wayan Warmada ${ }^{2}$, Arifudin Idrus ${ }^{2}$, Agung Harijoko ${ }^{2}$, Reza Al-Furqan ${ }^{3}$, \\ and Koichiro Watanabe ${ }^{4}$ \\ ${ }^{1}$ Department of Geology, Mandalay University, Mandalay, Myanmar \\ ${ }^{2}$ Geological Engineering Department, Faculty of Engineering, Gadjah Mada University, Yogyakarta, Indonesia \\ ${ }^{3}$ PT. Eksplorasi Nusa Jaya/Freeport-McMoran Copper \& Gold \\ ${ }^{4}$ Department of Earth Resources Engineering, Faculty of Engineering, Kyushu University, 744 Motooka, Nishi-ku, \\ Fukuoka 819-0395, Japan
}

\begin{abstract}
Characterization of hydrothermal alteration in the Cijulang area (West Java, Indonesia) was carried out using shortwave infrared spectroscopy. Hydrothermal alteration in the Cijulang area occurs in the calc-alkaline volcanic and volcaniclastic rocks. Shortwave infrared spectroscopic measurements of reflectance for altered rocks and minerals were carried out by ASD-FieldSpec and the laboratory spectra acquired were then analysed with "The Spectral Geologist" software program. Shortwave infrared spectroscopy is capable of detecting most finegrained alteration minerals from different hydrothermal alteration zones. Characteristic alteration minerals identified from the SWIR technique include pyrophyllite, alunite, kaolinite, dickite, illite, montmorillonite, polygorskite, gypsum, epidote, paragonite, and muscovite. Most of the spectra show mixture of alteration minerals and only a few display pure spectra of single mineral. The crystallinity of kaolinite from the samples was also determined from the reflectance spectra and show moderately to high crystallinity. Alteration system of the Cijulang prospect is similar to others documented high-sulfidation epithermal deposits, such as Rodalquilar (Spain), Summitville (Colorado), and Lepanto (Philippines). A characteristic alteration sequence and zonation of
\end{abstract}

${ }^{*}$ Corresponding author: M.M. TUN, Department of Geology, Mandalay University, Mandalay, Myanmar. Email: mintunmyo@gmail.com advanced argillic, argillic and propylitic alteration outward from the silica core has resulted from the progressive cooling and neutralization of hot acidic magmatic fluid with the host rocks.

Keywords: Cijulang, High-sulfidation, Alteration minerals, Shortwave Infrared Spectroscopy

\section{Introduction}

Shortwave infrared reflectance (SWIR) spectroscopy has been widely used in hydrothermal alteration mapping of various types of mineral deposits, such as high- and low-sulfidation epithermal, mesothermal, porphyry, sedimenthosted gold and copper, uranium, volcanogenic massive sulfide (VMS) and kimberlite. SWIR spectroscopy involves detection of the energy generated by vibrations within molecular bonds in the 1300- to 2500-nm (SWIR) range of electromagnetic spectrum (Thompson et al., 1999). Most minerals exhibit characteristic spectrum and major diagnostic absorption features in this SWIR region as a result of bending and stretching of certain molecules and radical, including $\mathrm{OH}, \mathrm{H}_{2} \mathrm{O}, \mathrm{NH}_{4}$, and Cation-OH bonds (such as $\mathrm{AlOH}, \mathrm{MgOH}$ and $\mathrm{FeOH}$ ) (Pontual et al., 1997a; Thompson et al., 1999). The spectral absorption features associated with different silicates occur at or near $1400 \mathrm{~nm}(\mathrm{OH}$ and water) and 1900nm (water) whereas other important 
and diagnostic spectral absorption features related to cation-OH bonds such as $\mathrm{AlOH}, \mathrm{FeOH}$ and $\mathrm{MgOH}$ occur at or near 2200nm, 2250nm and 2330nm respectively (Figure 1). The absorption features that represent these bonds or mineral groups are characteristic of hydrothermal alteration and mineral groups belonging to kaolinite, halloysite, pyrophyllite, smectite clays, dickite, micas, chlorites, alunite, jarosite, calcite (Pontual et al., 1997).

Reflectance spectra can be acquired by field portable spectrometers, such as GER-IRIS, ASD-FieldSpec and PIMA or by airborne remote sensing. Application of spectrometers allows rapid identification of the fine-grained hydrothermal alteration minerals which are generally difficult to identify by conventional macroscopic observation. SWIR spectroscopy not only detects the presence of minerals in the sample but also determines the relative abundance of mineral within the samples. Moreover, mineralogical and compositional variation in certain specific mineral species can also be recognized by the SWIR technique (Thompson et al., 1999).

Cijulang area is located in the Garut Regency of West Java, Indonesia (Figure 2) and the prospect has been explored by PT Aneka Tambang since 1994. This research aims to explore the characteristics of the hydrothermal alteration associated with pyrite-enargite-gold mineralization in the Cijulang prospect by the application of reflectance spectroscopy.

\section{Research methods}

Field investigation was carried out in the Cijulang area of West Java, Indonesia during March, 2013. A total of 70 altered rock and clay samples were collected from different hydrothermal alteration zones. Study on alteration mineralogy was carried out by Shortwave Infrared Spectroscopy (SWIR) aided by petrographic microscopy, X-Ray Diffraction and SEM-EDS analyses.

Shortwave infrared (SWIR) spectroscopic measurement of reflectance for altered rocks and clay minerals was carried out by Analytical Spectral Devices (ASD-FieldSpec), a spectro- radiometer which collected the reflectance in the 350 to $2500 \mathrm{~nm}$ spectral range. The reflectance spectra acquired by ASD device were then analyzed with "The Spectral Geologist ${ }^{\mathrm{TM}}$ (TSG)" software. The TSG provides automated assistance in the mineral identification and statistical analysis of the spectra. Mineral identification was conducted by spectral matching with reference library spectra. The Spectral Assistant (TSA) in The Spectral Geologist uses a library of 551 spectra of pure minerals and water. The software identifies a maximum of three minerals assigning relative weights and an error of matching. The relative weight does not represent the abundance of minerals in the samples but it reflects the relative proportion of one mineral to another which is influenced by grain size and distribution of the minerals. The level of confidence in the mineral identification is indicated by the error of matching.

Interpretation of spectral data from TSG software were cross-checked by spectral interpretation field manual and USGS library spectra. Identification of the mineral is based on the following spectral characteristics; wavelength position, intensity and shape of the absorption troughs and the overall shape of the entire spectrum. Shifting of the wavelength positions of diagnostic absorption feature represents compositional variation in minerals whereas variation in depth or width of the absorption feature reflects the variation in crystallinity or the grain size of the relative abundance of mineral (Pontual et al., 1997).

Bulk rock powdered and clay fraction samples were analyzed by Rigaku RINT-2100 Diffractometer at Laboratory of Earth Resources Engineering Department, Faculty of Engineering, Kyushu University. X-ray diffraction analysis was done using $\mathrm{CuK} \alpha$ radiation at $40 \mathrm{kV}$ and $20 \mathrm{~mA}$. Microprobe examination of alteration minerals was carried out by SHIMADZU SS-550 Scanning Electron Microscope equipped with a genesis-2000 EDX Spectrometer at the Centre for Advanced Instrumental Analysis, Kyushu University, Japan. Experimental condition for the analysis was performed at an accelerating potential of $15 \mathrm{kV}$, beam current about $10 \mathrm{~mA}$, and $3 \mu \mathrm{m}$ beam diameter. 


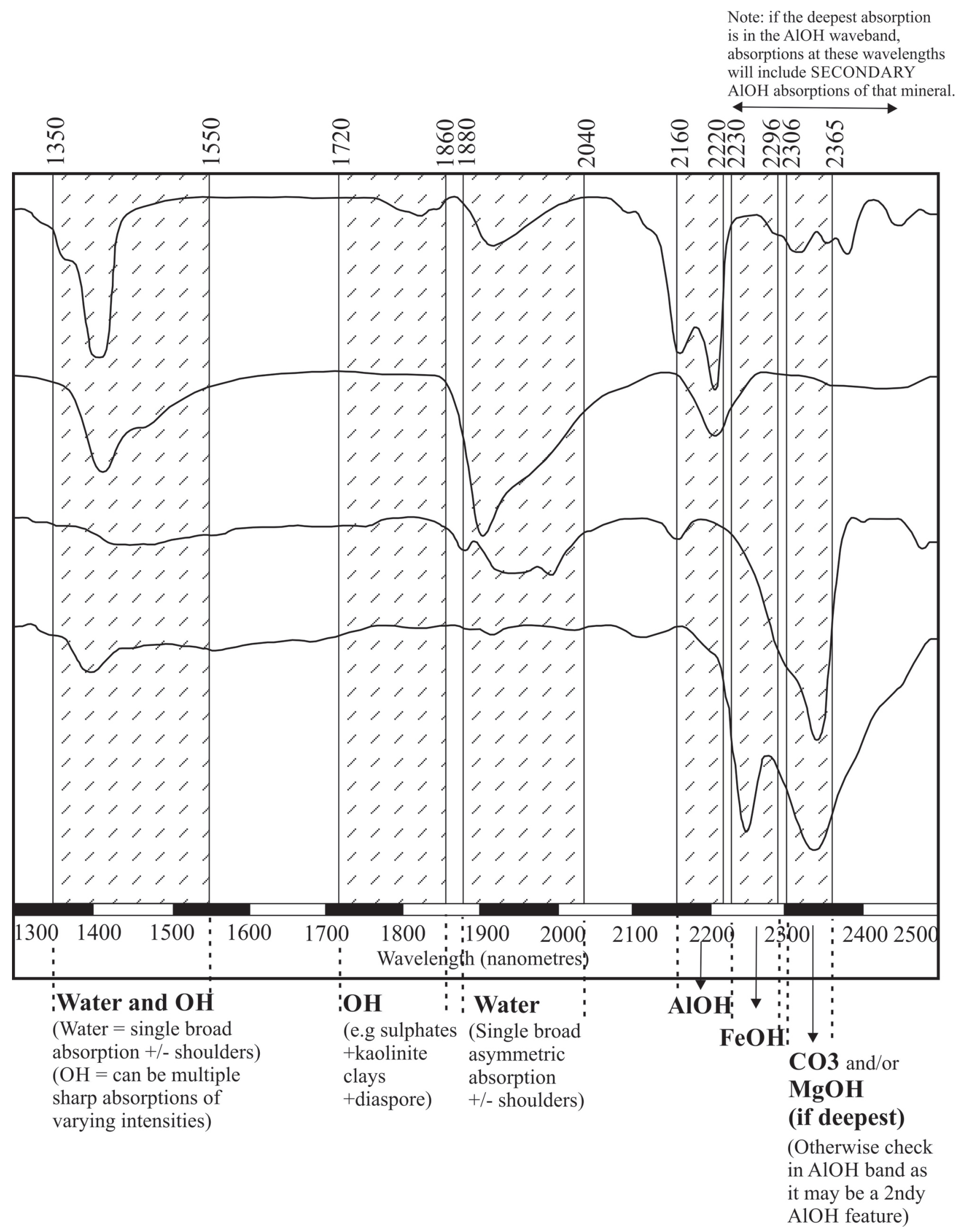

Figure 1: Major spectral absorption features in SWIR range (1300-2500nm) (Pontual et al., 1997a). 


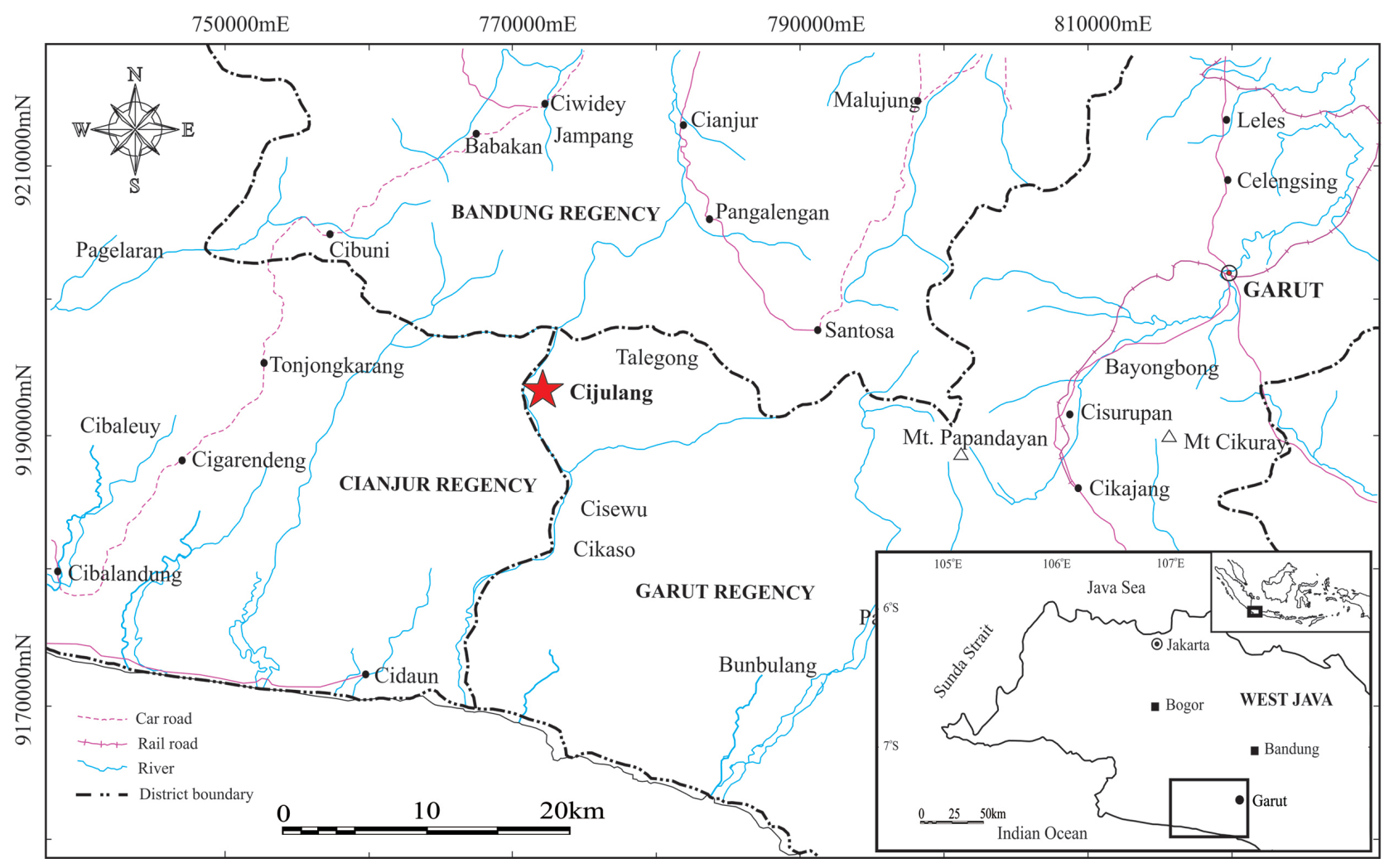

Figure 2: Location map of Cijulang area, Garut Regency, West Java, Indonesia.

\section{Results and Discussion}

\subsection{Alteration Minerals}

Hydrothermal alteration minerals identified from reflectance spectra of altered rocks and clay minerals include kaolinite, dickite, pyrophyllite, illite, muscovite, chlorite, alunite, epidote, polygorskite, and goethite. Most of the spectra show a mixture of these alteration minerals and only a few show pure spectra of single minerals. The common mineral assemblages identified from the reflectance spectroscopy include pyrophyllite-kaolinite, dickite-pyrophyllite, alunite-dickite, alunitekaolinite, kaolinite-illite, illite-montmorillonite and chlorite-montmorillonite (Figures $3 \mathrm{~B}$ and 3b).

\subsection{SWIR Spectral Characteristics of Alter- ation Minerals}

\section{Kandite group minerals}

Kaolinite $\left[\mathrm{Al}_{2} \mathrm{Si}_{2} \mathrm{O}_{5}(\mathrm{OH})_{4}\right]$. Kaolinite generally occurs as pure mineral spectra or mix spec- tra with other mineral such as dickite, pyrophyllite and illite. Kaolinite spectra have the following major absorption features: hydroxyl $(\mathrm{OH})$ stretching doublet around 1400nm and $1411 \mathrm{~nm}$, water $\left(\mathrm{H}_{2} \mathrm{O}\right)$ absorption feature at 1913nm and Al-OH diagnostic double absorption feature at $2168 \mathrm{~nm}$ and 2208nm (Figure $3 \mathrm{a}$ ).

Dickite $\left[\mathrm{Al}_{2} \mathrm{Si}_{2} \mathrm{O}_{5}(\mathrm{OH})_{4}\right]$. Dickite is one of the kandite group minerals commonly found in the Cijulang prospect. It occurs as pure mineral spectra or mix spectra with other minerals, such as pyrophyllite and kaolinite (Figure 3 a). Spectral characteristics of dickite are similar to those of kaolinite. It has hydroxyl doublet absorption features occurring around 1390nm and 1415nm. Al-OH diagnostic double absorption features exhibiting at $2172 \mathrm{~nm}$ and $2208 \mathrm{~nm}$, which are common characteristic of kandite group minerals (Figure 33).

Pyrophyllite $\quad\left[\mathrm{Al}_{2} \mathrm{Si}_{4} \mathrm{O}_{10}(\mathrm{OH})_{2}\right]$. Pyrophyllite spectra show absorption features at 1391$1396 \mathrm{~nm}$ and $1411-1414 \mathrm{~nm}$ due to vibration of 

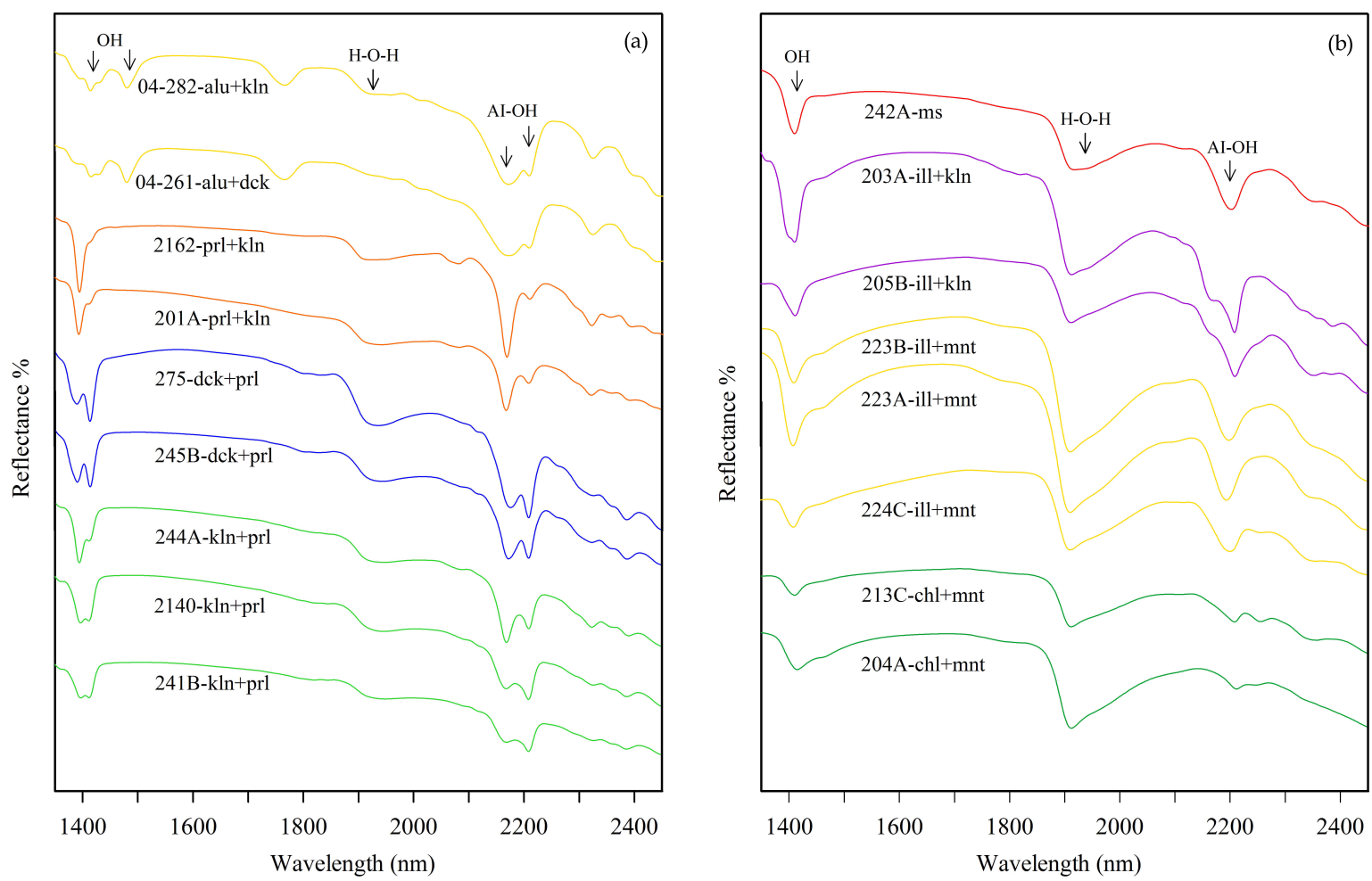

Figure 3: Reflectance spectra of alteration mineral mixtures from different hydrothermal alteration zones (a) advanced argillic and (b) argillic and propylitic. Kln-kaolinite, Prl-pyrophyllite, Dckdickite, Alu-alunite, Ill-illite, Mnt-montmorillonite, Chl-chlorite, Ms-muscovite.

hydroxyl ions $\left(\mathrm{OH}^{-}\right)$and water molecules $(\mathrm{H}-$ $\mathrm{O}-\mathrm{H})$, a doublet absorption feature at $2168 \mathrm{~nm}$ and 2208nm due to vibrational processes associated with $\mathrm{Al}-\mathrm{OH}$ bonds. Pyrophyllite is either seen as pure spectra or mixture with kaolinite (well crystalline) and dickite in the advanced argillically-altered samples (Figure $3 \mathrm{a}$ ).

\section{Smectite Group Minerals}

Montmorillonite [(Na,Ca $)_{0.33}(\mathrm{Al}, \mathrm{Mg})_{2}\left(\mathrm{Si}_{4} \mathrm{O}_{10}\right)$ $(\mathrm{OH})_{2} \cdot n \mathrm{H}_{2} \mathrm{O}$ ]. Montmorillonite spectra have characteristic sharp minima and asymmetric shape of water absorption features at 14091411nm and 1911-1914nm (Figure 3b). A broad diagnostic Al-OH absorption feature generally occurs at $2208 \mathrm{~nm}$, a typical feature of aluminum-bearing clays (Hunt, 1979).

\section{APS Group Minerals}

Alunite $\left[(\mathrm{K}, \mathrm{Na}) \mathrm{Al}_{3}\left(\mathrm{SO}_{4}\right)_{2}(\mathrm{OH})_{6}\right]$. Alunite is a diagnostic mineral of high-sulfidation epithermal system. Compositional variation in alunite- group minerals are recognized by shifts in the 1480nm spectral position, with value ranging from $\sim 1461 \mathrm{~nm}$ (NH4), to $\sim 1478 \mathrm{~nm}$ (pure K), to $\sim 1496 \mathrm{~nm}(\mathrm{Na})$ to $1510 \mathrm{~nm}(\mathrm{Ca})$ (Thompson et al., 1999). Alunite from the Cijulang prospect is only found in the drill core section and generally associated with pyrite and quartz. Alunite is identified as potassium end-member (K-alunite) and its spectra have major characteristic alunite absorption features: hydroxyl $(\mathrm{OH})$ stretching doublet occurring at 1428nm and $1480 \mathrm{~nm}$, diagnostic absorption feature at $1766 \mathrm{~nm}$ and the $\mathrm{Al}-\mathrm{OH}$ diagnostic absorption features at 2171nm, 2208 $\mu \mathrm{m}$ and 2324nm (Figure 3 a). Alunite generally occurs as mix spectra with other minerals, such as dickite and kaolinite.

\section{Illite Group Minerals}

Muscovite $\left[\mathrm{KAl}_{2}\left(\mathrm{AlSi}_{3} \mathrm{O}_{10}\right)(\mathrm{F}, \mathrm{OH})_{2}\right]$. White micas generally have absorption features occurring in the range between $2180 \mathrm{~nm}$ to $2228 \mathrm{~nm}$ due to the Al-OH bonds (Figure $3 \mathrm{~b}$ ). Varia- 
tion in chemical composition strongly affects the position of absorption in white micas; Narich micas have absorption features around 2200nm, whereas Mg-FeOH-rich and potassic micas have similar features occurring in the ranges between 2216-2228nm and 22002208nm respectively (Pontual et al. 1997). Muscovite generally occurs as mixture with well crystalline kaolinite has the following spectral characteristic; hydroxyl $(\mathrm{OH})$ absorption features at $1410 \mathrm{~nm}$, water $\left(\mathrm{H}_{2} \mathrm{O}\right)$ absorption feature at $1917 \mathrm{~nm}$ and $\mathrm{Al}-\mathrm{OH}$ absorption feature at $2202 \mathrm{~nm}$. It is classified as Na-rich type by its $\mathrm{Al}-\mathrm{OH}$ value occurring at 2200nm (Figure $3 \mathrm{~b})$.

Illite $\left[\mathrm{K}, \mathrm{H}_{3} \mathrm{O}\right)(\mathrm{Al}, \mathrm{Mg}, \mathrm{Fe})_{2}(\mathrm{Si}, \mathrm{Al})_{4} \mathrm{O}_{10}\left[(\mathrm{OH})_{2}\right.$, $\left(\mathrm{H}_{2} \mathbf{O}\right)$ ]. Illite has similar spectral characteristic to muscovite. Illite can be distinguished from muscovite by its deep absorption feature occurring at $1900 \mu \mathrm{m}$ due to molecular water within its crystal lattice (Figure 3b) (Pontual et al. 1997). Absorption feature occurring at $\sim 2200 \mathrm{~nm}$ reflects compositional variation in illite, those near $2190 \mathrm{~nm}$ are more sodic whereas these feature close to $2206 \mathrm{~nm}$ are more potassic (Halley, 2010). Illite shows hydroxyl $(\mathrm{OH}) \mathrm{ab}-$ sorption feature at $1409-1411 \mathrm{~nm}$, water $\left(\mathrm{H}_{2} \mathrm{O}\right)$ absorption feature at $1911-1914 \mathrm{~nm}$ and $\mathrm{Al}-\mathrm{OH}$ absorption feature centered at or near 2200nm, which is a diagnostic absorption feature of white micas. Illite from the Cijulang area is identified as paragonitic illite (Figure $3 \mathrm{~b}$ ).

\section{Other Minerals}

Other minerals such as Fe-chlorite, epidote, gypsum, palygorskite and goethite occur as mixture with other minerals in the analyzed samples. No pure spectra were obtained for these minerals and it was difficult to characterize their spectral characteristics. Anhydrous silicates and sulfides such as quartz and pyrite are difficult to identify because they show no absorption features in the shortwave infrared wavelength region. In addition, minerals present in amount less than $5 \%$ in the samples were not identified by the SWIR spectroscopy. The presence of such minerals was confirmed by the X-ray diffraction analysis.

\section{Kaolinite Crystallinity}

Kaolinite is the most common and abundant mineral in the hydrothermal alteration of the Cijulang area. So, it is important to determine the crystallinity of kaolinite. Kaolinite crystallinity determination was based on the analysis of shape and wavelength spacing of the $\mathrm{Al}-\mathrm{OH}$ band doublets absorption features (Figure 4a) by using slope parameters in the 2160$2180 \mathrm{~nm}$ wavelength region which is generally referred to as slope '2160' and slope '2180' parameters. Evaluation shows that the kaolinite from the Cijulang is characterized by moderate to high crystallinity (Figure $4 \mathrm{~b}$ ).

\subsection{Hydrothermal Alteration}

Hydrothermal alteration in the Cijulang area covers about $1 \times 2 \mathrm{~km}^{2}$ area of N-E trending elongate zone and hosted by andesitic lava, lapilli tuff and hydrothermal breccia. The distribution of alteration mineral assemblage indicates that Cijulang alteration is classified as epithermal high-sulfidation styles in which the silicic core is surrounded outward alteration mineral assemblages of advanced argillic, argillic and propylitic (Figure 5).

Silica alteration develops as both vuggy and massive silica. This alteration is easily recognized in the outcrop by weather-resistant bodies. Vuggy zone comprises residual silica remaining after loss of its reactive components by intense acid leaching. Massive silica is formed by secondary deposition of silica and later recrystallize to form quartz.

Advanced argillic alteration is the most widespread of alteration and identified by the presence of alunite, kaolinite, dickite, pyrophyllite, illite and pyrite in variable amount. The common mineral assemblages identified from SWIR spectroscopy include pyrophyllite+kaolinite, dickite+pyrophyllite, alunite+dickite, alunite+kaolinite and kaolinite+illite. Pyrophyllite, kaolinite and dickite are the dominant minerals of advanced argillic facies in the outcrop whereas alunite is observed only in the drill core section. Diaspore occurs locally in the advanced argillic alteration and generally associated with pyrophyllite. 

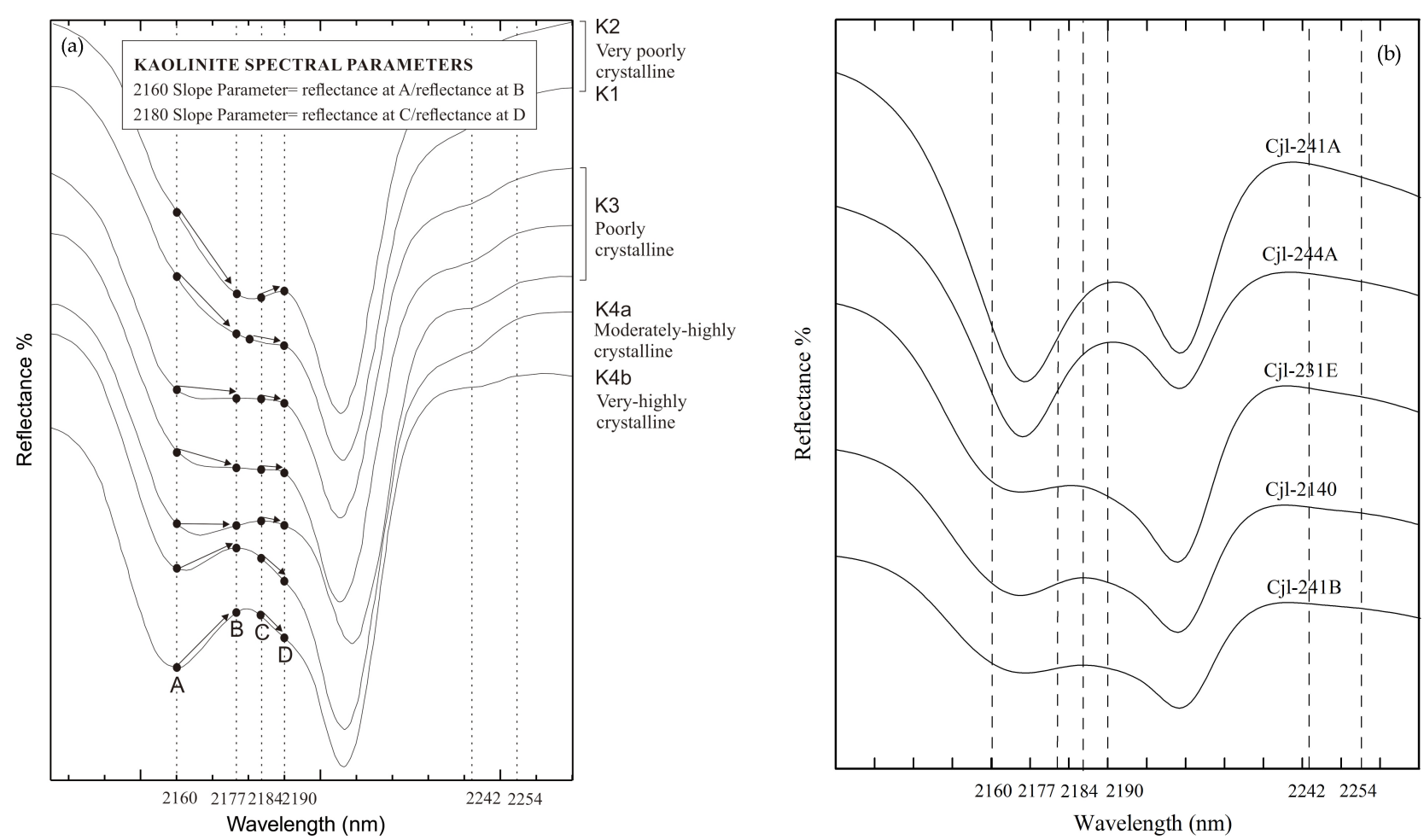

Figure 4: (a) Kaolinite crystallinity spectra shape and parameter guide (Pontual et al., 1997a) and (b) Reflectance spectra kaolinites from advanced argillic alteration zones of Cijulang prospect showing moderate to high crystallinity.

Argillic alteration is characterized by quartz, illite, paragonite, muscovite, kaolinite, smectite, illite-smectite and chlorite. The common assemblage is illite+montmorillonite. Propylitic alteration is composed of quartz, chlorite, epidote, illite, smectite, pyrite, hematite, goethite, carbonate, zeolite and magnetite. Phenocrysts and groundmass of host rock andesite lava and lapilli tuff are replaced by chlorite, sericite (illite), smectite, epidote, calcite, and albite. Chlorite and epidote tends to replace the mafic phenocrysts whereas as calcite and albite selectively replaces the plagioclase feldspar. Smectite generally replace the plagioclase and the groundmass is replaced by fine-grained chlorite, sericite, and epidote.

\section{Conclusion}

The application of reflectance spectroscopy enables to identify most hydrothermal alteration minerals related to the high-sulfidation mineralization in the Cijulang prospect. The minerals identified from SWIR spectroscopy help charac- terize the distinct alteration zonation which is significant in the determination of certain mineral deposit type.

Alteration system of the Cijulang prospect is similar to other systems that occur in welldocumented high-sulfidation epithermal deposits of the world (e.g., Rodalquilar, Spain; Summitville, Colorado; Lepanto, Philippines). A characteristic alteration sequence and zonation of advanced argillic, argillic and propylitic alteration outward from the silicic core has resulted from the progressive cooling and neutralization of hot acidic magmatic fluid with the host rocks (Arribas, 1995). Formation of vuggy silica requires the fluids of at least $\mathrm{pH}$ $\leq 2$ and at a temperature of $\sim 250^{\circ} \mathrm{C}$ (Stoffregen, 1987) to leach all the minerals from the volcanic hosts except quartz. High-sulfidation epithermal system, which is characterized by advanced argillic alteration, has developed under relatively oxidized, acidic, $\mathrm{SO}_{4}$-dominated environment. Dominant pyrophyllite-kaolinite assemblage in the study area indicates that hy- 


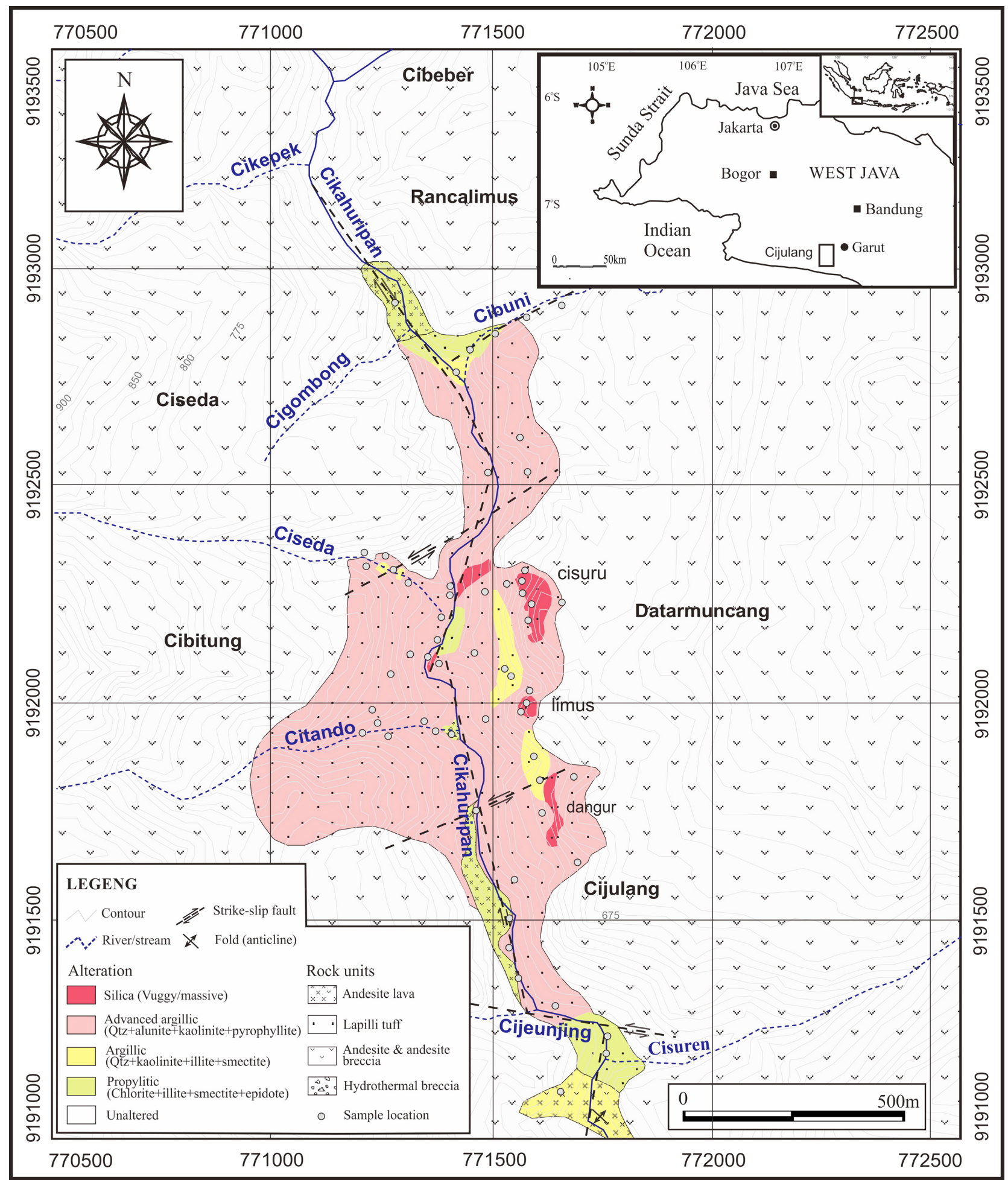

Figure 5: Hydrothermal alteration of Cijulang area, Garut Regency, West Java, Indonesia. 
drothermal fluids responsible for the alteration were silica-saturated and the temperature of formation may have been $>260^{\circ} \mathrm{C}$ (White and Hedenquist, 1990). The presence of pyrophyllite is an indication of deep-seated formation of the hydrothermal system.

\section{Acknowledgement}

The current research is supported by AUN/SEED-Net (JICA). Thanks are given to the PT Aneka Tambang (Persero) Tbk for permission to conduct research works in the concession area and help during field investigation.

\section{References}

Arribas, A., Jr. (1995) Characteristics of high sulfidation epithermal deposits and their relation to magmatic fluid. Mineralogical Association of Canada Short Course, v. 23, p. 419-454.

Halley, S.W. (2010) Mapping the footprints of hydrothermal systems: Geological Survey of Western Australia Record 2010/18, p. 264-265.

Hunt, G.R. (1979) Near-infrared (1.3-2.4um) spectra of alteration minerals: potential for use in remote sensing: Geophysics, v. 44, p. 1974-1986.

Pontual, S., Merry, N., and Gamson, P. (1997a) G-Mex Vol. 1, Spectral interpretation field manual: AusSpec International Pty. Ltd.

Pontual, S., Merry, N., and Gamson, P. (1997b) G-Mex Vol. 2, Practical applications handbook: AusSpec International Pty. Ltd.

Pontual, S., Merry, N., and Gamson, P. (1997c) G-Mex Vol. 4, Epithermal alteration systems: AusSpec International Pty. Ltd.

Stoffregen, R. (1987) Genesis of acid-sulfate alteration and $\mathrm{Au}-\mathrm{Cu}-\mathrm{Ag}$ mineralization at Summitville, Colorado: Economic Geology, v. 82, p. 1575-1591.

Thompson, A.J.B., Hauff, P.L. and Robitaille, A. (1999) Alteration Mapping in Exploration: Application of Short-Wave Infrared (SWIR) Spectroscopy SEG Newsletter, 1999, Number 39, published by the Society of Economic Geologists, Littleton, Colorado.

White, N.C. and Hedenquist, J.W. (1990) Epithermal environments and styles of mineralization: Variations and their causes, and guidelines for exploration: Journal of Geochemical Exploration, v. 36, p. 445-474. 